\title{
Impact of Production System on Quality Indices Distribution in Butterhead Lettuce: A Comparative Study among Open Field and Greenhouse
}

Goñi, María $\mathbf{G}^{1,2,3 *}$, Moreira María del $\mathbf{R}^{1,3}$, Agüero María $\mathbf{V}^{1,3}$ and Roura Sara $\mathbf{I}^{1,3}$

${ }^{1}$ Consejo Nacional de Ciencia y Tecnología (CONICET), Rivadavia 1917 (C1033AAJ). Ciudad Autónoma de Buenos Aires, Argentina

${ }^{2}$ Agencia Nacional de Promoción Científica y Tecnológica (ANCyT). Godoy Cruz 2370 (C1425FQD). Ciudad Autónoma de Buenos Aires, Argentina

${ }^{3}$ Grupo de Investigación en Ingeniería de Alimentos, Facultad de Ingeniería, UNMdP, Juan B. Justo 4302, Mar del Plata (7600), Argentina

\begin{abstract}
Butterhead lettuce quality was followed through changes in physical, physiological, microbiological, nutritional and sensory indices during postharvest storage. Production was in greenhouses, traditional and mulch, and in the field. Greenhouse lettuce heads had higher nutritional and sensory quality at harvest and lower enzymatic browning. Increased exposure to environmental conditions for open field grown lettuce heads may initiate defense mechanisms that could affect texture, color and appearance. During refrigerated postharvest storage, greenhouse lettuce heads had better leaf color and texture and were less susceptible to enzymatic browning. There was no difference in postharvest shelf life for greenhouse and field grown plants. Production in greenhouses produced important marketing benefit, along greater weight per plant and leaf number, by increasing producer profitability.
\end{abstract}

Keywords: Ascorbic acid; Enzymatic browning; Lactuca sativa, Overall visual quality; Postharvest; Preharvest; Shelf life

\section{Introduction}

Lettuce (Lactuca sativa var. Lores, variety Longifolia, Longifolia Group) is often associated with health benefits due to the presence of antioxidant components [1-3]. Postharvest quality of lettuce is influenced by time of harvest or maturity at harvest and postharvest storage temperature and relative humidity; growing season environmental conditions that include light, average temperature, minimum temperature, and night-day temperature difference, and irrigation, fertilization, and cultivation method [4,5].

Butterhead lettuce is basically grown under two production systems: open field and protected culture using greenhouses. The need to provide fresh quality products during prolonged periods of the year, along with a more efficient use of water had led to the adoption of greenhouses [6]. Greenhouse production is widespread worldwide, and lettuce is globally one of the vegetables produced using this technology. It is common in lettuce production to either use or not use soil covering plastic mulch in the greenhouse system.

The plastic cover used on the greenhouses changes the internal radiation balance with respect to the external environmental reducing light input by at least 30\% [7], which may affect the lettuce quality. The soil cover changes the immediate environment around the plant, especially affecting the radiation balance around the lettuce head. Plastic mulch, affects the water balance and the temperature regime of the plant microenvironment [8].

The use of mulching improves quality and productivity [9]. Under greenhouse conditions with or without there were differences in Butterhead lettuce initial counts, evolution and tolerance to refrigeration temperatures of some microbial populations [10]. Goñi et al. [11] reported for freshly harvested Butterhead lettuce there were differences in water status indices between mulched and unmulched lettuce plants. The impact of the production system on postharvest quality retention during storage was not established.

Placing the plant in dispirit production systems constitutes a biological model to elucidate effects of conditions during production on quality indices. Postharvest changes in quality indices of Butterhead lettuce, as affected by production systems, were followed during storage.

\section{Materials and Methods}

\section{Plant material and sample preparation}

The experiments took place in Sierra de los Padres, Mar del Plata, Argentina (South $37^{\circ} 57^{\prime}$ West $57^{\circ} 42^{\prime}$ ). Butterhead lettuce plants, var. Lores, were utilized for all studies. Three production systems were used; two were mulched (black plastic sheeting) and unmulched plants in greenhouses and, in the third system, plants were grown under field conditions. The mulch used in the greenhouses was polyethylene (Cristal Agroman, Beniplast, Argentina, $150 \mu \mathrm{m}$ thickness) and the material used for mulching was black low-density polyethylene (Agroman Mulching, Beniplast, Argentina, $100 \mu \mathrm{m}$ thick).

In all production systems, lettuce plants were subjected to the recommended irrigation regime to their specific requirements. The fields were on closely located to assure that the geographical and weather effects were similar; lettuce were grown in the same season (spring/summer). Harvest was at optimal maturity after head formation was completed.

After harvest, heads were immediately pre-cooled and transported to the laboratory. Five heads were analyzed to determine quality indices values at harvest. Other lettuce heads were placed individually

*Corresponding authors: Goñi MG, Grupo de Investigación en Ingeniería de Alimentos, Facultad de Ingeniería, UNMdP, Juan B. Justo 4302, Mar del Plata (7600), Argentina, E-mail: ggoni@fi.mdp.edu.ar

Received October 27, 2013; Accepted November 14, 2013; Published November 18, 2013

Citation: María GG, María del RM, María VA, Sara I R (2013) Impact of Production System on Quality Indices Distribution in Butterhead Lettuce: A Comparative Study among Open Field and Greenhouse. J Nutr Food Sci 3: 241. doi: 10.4172/21559600.1000241

Copyright: @ 2013 María GG, et al. This is an open-access article distributed unde the terms of the Creative Commons Attribution License, which permits unrestricted use, distribution, and reproduction in any medium, provided the original author and source are credited. 
in polyethylene bags (with an $\mathrm{O}_{2}$ permeability $600 \mathrm{~cm}^{3} \mathrm{~m}^{-2} \mathrm{~d}^{-1}, \mathrm{CO}_{2}$ permeability $4000 \mathrm{~cm}^{3} \mathrm{~m}^{-2} \mathrm{~d}^{-1}$, and water vapor permeability $4 \mathrm{~g} \cdot \mathrm{m}^{-2} \mathrm{~d}^{-1}$ ), heat sealed and stored in a refrigerated chamber at $0-2^{\circ} \mathrm{C}$ and $97-99 \%$ relative humidity. Under this temperature, respiration rate, ethylene production, and other physiological changes were minimized.

\section{Vegetative growth parameters}

Yield was evaluated by: lettuce head weight, number of leaves per head, and leaf area. Each plant was weighed and all leaves detached and counted. Leaf area was determined with a method of Goñi et al. [11]. The technique consisted of tracing the leaf shape onto clear paper, cutting it and measuring it using an Area Measurement System (Delta T-Devices Ltd., Cambridge, England).

\section{Quality indices}

Quality indices measured were from the external (outer leaves), middle (mid leaves) and internal (inner leaves) zones. For each head, zones were visually delimited, according to organoleptic criteria established by Agüero et al. [8]. Each zone had a mean of approximately 6 to 9 leaves.

\section{Physiological quality}

Water status was determined as reported by Viacava et al. [12] with the indices: Water Content (WC), Relative Water Content (RWC), Free Water (FW), Bound Water (BW) and the ratio FW and Total Water (FW/TW).

\section{Nutritional quality}

Reduced ascorbic acid content (AA) was determined by the titrimetric assay described by Roura [13] using 2, 6-dichloroindophenol as titrant solution.

\section{Microbiological studies}

Total microbial counts were evaluated with the methodology of Ponce et al. [10]. Ground lettuce from each head zone was macerated (Stomacher 400 Circulator Homogenizer, London, UK) in a buffer solution $\left(\mathrm{PO}_{4} \mathrm{~K}_{3}, \mathrm{pH}=7.2\right)$. Total microbial counts were on plate count agar after incubation for $48 \mathrm{hr}$ at $30^{\circ} \mathrm{C} \mathrm{[14]}$. Total microbial counts were performed in triplicate.

\section{Physicochemical quality}

Color determination was done using a tristimulus colorimeter SP60 (Lovibond, Solstice Park, Amesbury, United Kingdom). The instrument was calibrated with a standard white plate $(\mathrm{Y}=93.2, \mathrm{X}=0.3133$, $\mathrm{Z}=0.3192$ ). Leaf color was measured by $\mathrm{L}^{*}, \mathrm{a}^{*}$ and $\mathrm{b}^{*}$ chromaticity coordinates of the CIELab scale [15]. Measurements were performed in ten different positions on leaves. Using the $\mathrm{L}^{\star}, \mathrm{a}^{\star}$ and $\mathrm{b}^{\star}$ values, a color index (CI) was determined [16].

Chlorophyll content of each zone was determined following the methodology of Moreira using a cold solution 18:1 propanone:ammonium hydroxide $(0.1 \mathrm{~N})$ as extraction solution [17] The homogenate was filtered through sintered glass and water removed from the filtrate with anhydrous sodium sulfate. The filtrate absorbance at 660.0 and $642.5 \mathrm{~nm}$ was measured with a UV $1601 \mathrm{PC}$ UV-visible spectrophotometer (Shimadzu Corporation, Kyoto, Japan).

\section{Sensory quality}

Sensory analysis was performed as described by Agüero et al. [8]. At each storage time, each individual head was subjected to a sensory panel to evaluate the overall visual quality (OVQ) of each plant zone. The panel consisted on 9 judges, aged 30 to 55 years old, with previous sensory evaluation experience in leafy vegetables. Samples were presented in random order to judges who made independent evaluations. The OVQ was evaluated on leaf color (shade and uniformity), brightness, texture, and presence or absence of defects. A 9-point scoring scale was used, in which 9 was excellent quality and 1 was very poor quality; the acceptance limit was 5 (poor quality). Judges were asked to evaluate the presence of enzymatic browning in the butt stem (EBB) and leaves (EBL). A 5-point scale was used for these indices, in which 1 was absence of enzymatic browning and 5 was excessive enzymatic browning; 3 was the acceptance limit.

\section{Statistical analysis}

Data were analyzed with SAS, ver. 9.0 [18]. PROC GLM (general linear model procedure) was used for the analysis of variance (ANOVA) and PROC UNIVARIATE was used to validate the ANOVA. Factors used as sources of variation were: PREHARV (production system: open field, unmulched or mulched in greenhouses), DAY (storage time, day of sampling: 0, 2, 4 and 10), ZONE (zones of lettuce head: external, middle and internal), and the corresponding interactions were used for postharvest changes analysis. Only PREHARV and ZONE were used as factors for quality indices at harvest. Results reported are LSMEAN values (estimators of means by the least squares method). When significant effects were found, the Tukey-Kramer multiple comparison test was performed [19].

\section{Results and Discussion}

\section{Vegetative growth parameters}

Values of vegetative growth parameters to compare yield varied (Table 1). There was an effect of the factor PREHARV, with lettuce heads from open field being lighter than those from greenhouses (mulched and unmulch, without significant differences between them). Produce

\begin{tabular}{|c|c|c|c|c|}
\hline & & \multicolumn{3}{|c|}{ Production system } \\
\hline & & Traditional Greenhouse & Mulch greenhouse & Open field \\
\hline \multicolumn{2}{|c|}{ Lettuce head weight $(\mathrm{g})^{*}$} & $373.8^{A} \pm 96.7$ & $388.7^{A} \pm 70.8$ & $352.0^{\mathrm{B}} \pm 59.1$ \\
\hline \multicolumn{2}{|c|}{ Total leaf number* } & $20^{A} \pm 1$ & $23^{\mathrm{A}} \pm 1$ & $34^{\mathrm{B}} \pm 2$ \\
\hline \multirow{3}{*}{$\begin{array}{l}\text { Leaf areał } \\
\left(\mathrm{cm}^{2}\right)\end{array}$} & External & $306.6^{\mathrm{Aa}} \pm 47.7$ & $323.0^{\mathrm{Aa}} \pm 41.7$ & $238.8^{\mathrm{Ba}} \pm 55.0$ \\
\hline & Middle & $240.9^{\mathrm{Ab}} \pm 95.7$ & $254.8^{\mathrm{Ab}} \pm 76.5$ & $188.0^{\mathrm{Bb}} \pm 39.1$ \\
\hline & Internal & $42.7^{\mathrm{Ac}} \pm 12.3$ & $116.5^{\mathrm{Bc}} \pm 14.6$ & $80.2^{\mathrm{Cc}} \pm 16.8$ \\
\hline
\end{tabular}

* Zones were not defined; therefore only between production systems comparisons were performed. Different uppercase letters indicate significant differences between production systems $(p<0.05)$

łLsmean values are reported, different lowercase letters indicate significant difference between zones $(p<0.05)$ and uppercase letters indicate significant differences between production systems $(p<0.05)$

Table 1: Mean values at harvest of vegetable growth parameters of lettuce heads produced under different systems. 
obtained using greenhouses systems resulted in the heaviest heads and this could be due to the more controlled environmental conditions in the greenhouse.

Total leaf number was reduced in lettuce plants from greenhouses compared to open field. Plants from field culture had the higher leaf number in the external, older and green mature zone with respect to greenhouse lettuce.

Inversely, leaf area corresponding to leaves from external and middle zones in greenhouse lettuce heads, was significantly higher compared to leaves from the open field. Internal leaves presented a similar profile, being higher for greenhouse lettuce in respect to those from the open field. Leaf area is an important variable considered in most physiological and agronomic studies as it is correlated with light interception, photosynthetic efficiency, evapotranspiration and plant growth [20]. The single biggest driving force for biomass generation is light interception, which could be improved when leaf area is increased. Light intensity is often limited in a greenhouse and can be half that found in the field. Additionally, the plastic cover used in greenhouses changes the internal radiation balance compared to external conditions [6]. Differences found in leaf area among lettuce heads from open field or greenhouses could be associated with radiation-related parameters. Leaf emergence and leaf expansion rates are influenced by temperature with increasing temperature an indirect way to improve light capture [21]. Greater leaf area in greenhouse lettuce heads may be an adaptation to enhance light capture to cover photosynthesis demands.

\section{Quality indices distribution in freshly harvested lettuce}

RWC provides information about leaf water content by measuring the amount of water in the leaf tissue in relation to fully turgid tissue [22]. An interaction occurred between ZONE and PREHARV. For each zone, no differences were detected in RWC between greenhouse lettuce, with mean values of $83.48,85.15$ and $85.77 \%$ for outer-, midand inner-leaves, respectively (Table 2) while RWC in open field lettuce was nearly $8 \%$ lower. Inner leaves presented higher RWC values than outer leaves for open field and unmulched greenhouse lettuce, but these increments were absent in mulch greenhouse heads that had similar RWC in all three zones. Goñi et al. [11] had similar results by doing a characterization of Butterhead lettuce heads produced in mulched and unmulched greenhouses. At harvest, open field lettuce had the lowest RWC values in the three zones. High air relative humidity, coupled with lower wind velocity inside the greenhouse, tends to reduce water vapor exchange between the canopy and the atmosphere compared to the open field. An 8\% drop in RWC could be regarded as mild water stress following Hsiao's classification [23]. Under moderate stress there is additional turgor reduction, leading to partial closure of stomata aperture and a reduction in photosynthetic activity. The lower RWC values for open field lettuce heads may indicate a moderate level of water stress compared with greenhouse produced lettuce heads. Inside greenhouses, lettuce plants develop in a more moderate environment. Differences in RWC between inner (younger) and outer leaves (older) could be attributed to metabolic differences instead of different exposure level to environmental conditions. Guerra et al. [24] found similar results for greenhouse celery (Apium graveolens L.), attributing differences to degree of tissue development.

Only PREHARV affected WC (Table 2). Open field lettuce heads had the lowest WC while greenhouse produced lettuce heads had the highest values for mulched and unmulched greenhouses. Open field produced lettuce heads underwent more severe climatic conditions than greenhouse produced lettuce plants, which may be responsible for lower WC values.
Production system affected initial FW and BW (Table 2) distribution, with an interaction between PREHARV and ZONE. No significant differences were detected in FW values between zones in plants cultivated in unmulched greenhouses; for mulched lettuce FW was higher in outer than middle and inner leaves. For open field lettuce higher values were in inner and middle leaves. For BW, lettuce heads from mulched and unmulched greenhouses had higher values in younger (inner) leaves; in open field plants higher values were in older leaves (outer). External leaves in mulch system had the highest FW value compared to those in the unmulched greenhouse and open field. Middle and internal zones had similar trends, but without differences to unmulched greenhouse system. For external and middle zones, the highest BW values were in open field plants, while the highest internal value was in mulched greenhouse lettuce heads. Once again, it was clear that the preharvest environment affected physiological indices distribution. A more efficient water use regime in the mulched lettuce plants could increase FW along the whole plant, resulting in better water status compared to the other production systems. Goñi et al. [11] reported higher FW for lettuce plants cultivated using mulch than in plants cultivated in the open field. As BW is often associated with tolerance to abiotic stress [25] increased values for outer- and midleaves from open field lettuce may be a tissue response to exposure to a preharvest moderate water stress.

The FW/TW profile in the lettuce head was dependent on production system (Table 2). Plants from greenhouses had a decrease in values from outer to inner leaves while plants cultivated in open field had the highest values in inner leaves decreasing towards outer leaves. External and internal zones had higher values in traditional greenhouse than mulched greenhouse and open field when comparison was in the same zone. The middle zone had a higher value in mulched than in unmulched greenhouses and open field.

The external and middle leaves from unmulched greenhouse lettuce heads had the highest AA while mulched lettuce had the lowest AA (Table 2). For inner leaves, AA was not different between production systems. Goñi et al. [11] found differences in initial AA, associating this result to production system and leaf maturity stage. The AA concentrations can vary, depending on maturity, genetic variations, preharvest conditions, postharvest handling, processing, and preparation [26-28]. Wojciechowska et al. [28] found lower AA in lettuce plants and celery grown in a greenhouse with mulching compared to unmulched greenhouses. Black plastic mulch intercepts incident radiation, affecting quantity and quality of photosynthetic active radiation (PAR) received by the plant [29] decreasing amounts of reactive oxygen species (ROSs) formed in leaves [30,31]. This decrease in oxidative stress may diminish the physiological response, inhibiting the AA synthesis in mulched lettuce plants. High AA concentrations in chloroplasts help protect tissues against damaging oxygen-derived species often produced during photosynthesis [32]. Mulched lettuce plants were grown in a more protected environment than those from open field and the milder conditions might cause a reduction in synthesis of AA. Oh et al. [33] found that slight variations in temperature or small periods of radiation intensities higher than normal, were sufficient to trigger defense mechanisms in lettuce tissue against oxidative stress. The AA variability at harvest could be associated to production system and also to leaf position within plants. Unmulched greenhouse lettuce plants had higher AA in outer and middle leaves. The AA in vegetable tissue is synthesized in a metabolic path closely related to photosynthesis [34]. External and middle leaves functioned as photosynthetic leaves and were exporters of photoassimilates. The fact that AA in these leaves was significantly higher than AA of inner leaves was a predictable result. 
Citation: María GG, María del RM, María VA, Sara I R (2013) Impact of Production System on Quality Indices Distribution in Butterhead Lettuce: A Comparative Study among Open Field and Greenhouse. J Nutr Food Sci 3: 241. doi: 10.4172/2155-9600.1000241

Page 4 of 10

\begin{tabular}{|c|c|c|c|c|c|c|c|c|c|}
\hline \multirow{3}{*}{\begin{tabular}{|l|} 
Quality index* \\
Lettuce zone
\end{tabular}} & \multicolumn{9}{|c|}{ Production System } \\
\hline & \multicolumn{3}{|c|}{ Traditional Greenhouse } & \multicolumn{3}{|c|}{ Mulch Greenhouse } & \multicolumn{3}{|c|}{ Open field } \\
\hline & External & Middle & Internal & External & Middle & Internal & External & Middle & Internal \\
\hline Relative Water Content (\%) & $84.50^{\mathrm{Aa}}$ & $85.43^{\mathrm{Aa}}$ & $85.00^{\mathrm{Aa}}$ & $82.47^{\mathrm{Aa}}$ & $84.87^{\mathrm{Aab}}$ & $86.53^{\mathrm{Ab}}$ & $75.80^{\mathrm{Ba}}$ & $76.02^{\mathrm{Ba}}$ & $78.97^{\mathrm{Bb}}$ \\
\hline Water Content $(\%)^{\mathrm{nsi}}$ & $95.82^{\mathrm{Aa}}$ & $95.53^{\mathrm{Aa}}$ & $95.07^{\mathrm{Aa}}$ & $93.93^{\mathrm{Ba}}$ & $93.13^{\mathrm{Ba}}$ & $93.07^{\mathrm{Ba}}$ & $91.83^{\mathrm{Ca}}$ & $91.57^{\mathrm{Ca}}$ & $92.20^{\mathrm{Ca}}$ \\
\hline Free Water Content $(\mathrm{g} / \mathrm{g})$ & $9.57^{\mathrm{Aa}}$ & $10.10^{\mathrm{Aa}}$ & $10.20^{\mathrm{Aa}}$ & $16.19^{\mathrm{Ba}}$ & $12.72^{\mathrm{Ab}}$ & $10.18^{\mathrm{Ac}}$ & $3.80^{\mathrm{Ca}}$ & $6.18^{\mathrm{Bb}}$ & $6.17^{\mathrm{Bb}}$ \\
\hline Bound Water Content (g/g) & $3.67^{\mathrm{Aa}}$ & $5.92^{\mathrm{Ab}}$ & $7.81^{\mathrm{Ac}}$ & $4.35^{\mathrm{Aa}}$ & $6.68^{\mathrm{Ab}}$ & $12.70^{\mathrm{Bc}}$ & $12.10^{\mathrm{Ba}}$ & $12.51^{\mathrm{Ba}}$ & $11.59^{\mathrm{Ba}}$ \\
\hline Free Water/Total Water Ratio & $0.73^{\mathrm{Aa}}$ & $0.63^{\mathrm{Ab}}$ & $0.57^{\mathrm{Ab}}$ & $0.79^{\text {Aa }}$ & $0.66^{\mathrm{Ab}}$ & $0.44^{\mathrm{Bc}}$ & $0.24^{\mathrm{Ba}}$ & $0.33^{\mathrm{Bb}}$ & $0.35^{\mathrm{Bb}}$ \\
\hline Acid Ascorbic Content (mg/100g FT) & $29.25^{\mathrm{Aa}}$ & $26.93^{\mathrm{Aa}}$ & $16.93^{\mathrm{Ab}}$ & $9.01^{\mathrm{Ba}}$ & $17.23^{\mathrm{Bb}}$ & $14.14^{\mathrm{Ab}}$ & $16.79^{\mathrm{Ca}}$ & $20.72^{\mathrm{Bb}}$ & $18.00 \mathrm{~A}^{\mathrm{ab}}$ \\
\hline Total Mesophyll Bacteria (log(CFU/g FT)) & $5.31^{\mathrm{Aa}}$ & $6.45^{\mathrm{Ab}}$ & $6.36^{\mathrm{Ab}}$ & $5.98^{\mathrm{Ba}}$ & $6.44^{\mathrm{Ab}}$ & $5.98^{\mathrm{Bb}}$ & $5.35^{\mathrm{Aa}}$ & $6.90^{\mathrm{Bb}}$ & $6.71^{\mathrm{cb}}$ \\
\hline Color Index (Cl) & $-6.64^{\mathrm{Aa}}$ & $-6.17^{\mathrm{Ab}}$ & $-5.20^{A C}$ & $-6.66^{\mathrm{Aa}}$ & $-5.98^{\mathrm{Ab}}$ & $-3.32^{\mathrm{BC}}$ & $-6.10^{\mathrm{Ba}}$ & $-5.58^{\mathrm{Ab}}$ & $-3.66^{\mathrm{Bc}}$ \\
\hline Chlorophyll content (mg/100gFT) & $37.27^{\mathrm{Aa}}$ & $32.23^{\mathrm{Aa}}$ & $12.21^{\mathrm{Ab}}$ & $43.05^{\mathrm{Ba}}$ & $34.44^{\mathrm{Ab}}$ & $9.89^{A C}$ & $45.03^{\mathrm{Ba}}$ & $41.20^{\mathrm{Ba}}$ & $18.91^{\mathrm{Bb}}$ \\
\hline Overall Visual Quality Score & $8.98^{\mathrm{Aa}}$ & $8.94^{\mathrm{Aa}}$ & $9.00^{\mathrm{Aa}}$ & $9.00^{\mathrm{Aa}}$ & $8.97^{\mathrm{Aa}}$ & $9.00^{\mathrm{Aa}}$ & $7.60^{\mathrm{Ba}}$ & $8.42^{\mathrm{Bb}}$ & $8.67^{\mathrm{Bc}}$ \\
\hline Enzymatic Browning in Leaves Score & $1.00^{\mathrm{Aa}}$ & $1.00^{\mathrm{Aa}}$ & $1.00^{\mathrm{Aa}}$ & $1.00^{\mathrm{Aa}}$ & $1.00^{\mathrm{Aa}}$ & $1.00^{\mathrm{Aa}}$ & $2.06^{\mathrm{Ba}}$ & $1.23^{\mathrm{Bb}}$ & $1.50^{\mathrm{Bc}}$ \\
\hline Enzymatic Browning in Butt stem Score ${ }^{\star *}$ & \multicolumn{3}{|c|}{$1.00^{\mathrm{A}}$} & \multicolumn{3}{|c|}{$1.00^{\mathrm{A}}$} & \multicolumn{3}{|c|}{$1.55^{\mathrm{B}}$} \\
\hline
\end{tabular}

*Lsmean values are reported, different lowercase letters indicate significant difference between zones $(p<0.05)$ and uppercase letters indicate significant differences between production systems $(p<0.05)$

nsi No significant interaction

** Zones were not defined for Enzymatic Browning in Butt stem Score, therefore only between production system comparisons were performed

Table 2: Quality indices distribution by both lettuce zone (external, middle and internal) and production system (open field, traditional greenhous and mulching greenhouse) at harvest.

Total microbial bacteria counts provide a useful estimate of total viable microbial population, and it is indicative of endogenous microflora and contamination undergone by the produce [35]. Bacteria found in fresh produce are the same than those normally found in field [36]; production system may have an effect on TMB of lettuce at harvest. The microbiological quality of lettuce heads was affected by the production system. The TMB counts were higher than $5 \log$ (Table 2 ) in the lettuce head zones whatever production system was used. Ponce found initial values higher than $5 \log$ in lettuce heads cultivated in greenhouses [10]. For unmulched greenhouse and open field, the external zone had lower TMB (mean of $5.33 \mathrm{log}$ for both systems) than middle and inner zones (mean of $6.61 \mathrm{log}$ for the two zones and two production systems). Fonseca [37] found similar results for Iceberg lettuce and they attributed this result to exposure of outer leaves to intermittent water stress which can result in higher accumulation of metabolites that diminish bacterial growth. For mulched lettuce heads, TMB was higher in the middle zone than in outer and inner zones, which were not different. Middle leaves of mulched lettuce heads may provide a safe environment to microorganisms, allowing native microflora to become established, resulting in higher counts. Open field and unmulched greenhouse lettuce heads were subject to environmental conditions more susceptible to change than mulched greenhouse lettuce heads; some defense mechanisms may be elicited as a result of those changes [37].

Production system also affected color parameters. Plants from unmulched greenhouse had a more uniform color distribution and a stronger green hue than open field or mulched greenhouse lettuce heads. The two latter have a significant color zonification within the plant (Table 2), with the lower CI values (greener) in outer leaves. Mid- and inner-leaves of unmulched greenhouse lettuce plants have darker green color than mulched and open field lettuce heads. The total chlorophyll content (TC) was affected by production method and plant zone. The initial TC of outer leaves was similar for open field and mulched lettuce plants (mean value of $44.0 \mathrm{mg} / 100 \mathrm{~g} \mathrm{FT}$ ) while it was slightly lower for unmulched greenhouse. Mid- and inner-leaves of open field lettuce plants had a higher TC than greenhouse lettuce. Agüero et al. [8] reported differences in TC between lettuce zones, and attributed the differences to amount of sun light exposure of outer leaves, which may have increased chlorophyll synthesis. Production system, affected TC with open field lettuce plants having the highest initial values of TC in all plant zones, probably associated with longer radiation exposure during growth. These results agree with Caldwell and Britz [38] working with lettuce.

Sensory quality was affected by production system and the head zone. Greenhouse lettuce had lower enzymatic browning scores in leaves and butt stem than open field lettuce (Table 2). Lettuce heads in unmulched and mulched systems produced optimal values in the plant zones. Lettuce heads produced in open field had slight enzymatic browning in leaves with higher scores (worst) in the external zone than in middle and internal ones. External leaves were more exposed to environmental conditions, and more susceptible to mechanical damage during harvest. Within the damaged leaf biochemical events that cause enzymatic browning could be triggered. Open field lettuce plants were exposed to UV-B solar radiation $(280-320 \mathrm{~nm})$ that leads to generation of ROSs. Outer leaves from lettuce cultivated in the open field may increase synthesis of phenolic compounds as a response to protect themselves from harmful radiation. As a consequence, an adjustment of antioxidant systems (polyphenols and other compounds) at cell and whole organism levels could take place $[39,40]$. This protective effect involves an increment susceptibility to enzymatic browning due to higher concentration of browning substrates, phenolic compounds. Similar enzymatic browning occurred in butt stem: optimal scores were obtained for the greenhouse systems while a slight degree of EBB was detected in open field lettuce plants.

Finally, overall visual quality of lettuce heads at harvest was optimal in all zones from lettuce plants obtained from greenhouses, without significant differences due to zone and mulch or unmulched systems. Open field lettuce plants had significantly lower OVQ scores in the three zones (Table 2). The reduction in OVQ score was especially noteworthy for external zone, with $11 \%$ reduction with respect to the other zones and $16 \%$ reduction with respect to the other production systems. Increased exposure to environmental conditions in open field plants when compared to greenhouse lettuce plants, may initiate defense mechanisms that affected quality. Changes in leaf morphology increases lignification of the cell wall or polyphenolic compounds synthesis might affect perception of texture, color and appearance of the plant causing lower OVQ scores [41]. These changes can be a plant response to cope with mild water stress and higher radiation exposure. 
Citation: María GG, María del RM, María VA, Sara I R (2013) Impact of Production System on Quality Indices Distribution in Butterhead Lettuce: A Comparative Study among Open Field and Greenhouse. J Nutr Food Sci 3: 241. doi: 10.4172/2155-9600.1000241

Page 5 of 10

\section{Postharvest changes in quality indices}

A significant triple interaction affected the evolution of RWC during postharvest storage (Figure 1). Mulched lettuce maintained almost constant RWC values throughout storage with slight differences among zones for external, middle and inner leaves, respectively. An increase in RWC occurred for unmulched greenhouse lettuce until day 10 of storage for all three zones; by day 14, RWC values were similar values to harvest. These results could be attributed to saturated relative humidity inside the package (97-98\%) maintaining cell membrane permeability. Differences between zones could be associated with location of the leaf inside the plant (related to degree of exposure to environmental conditions) and physiological differences among leaf tissues associated with leaf age, outer leaves older than inner leaves.

The WC (Figure 1) was strongly affected by production system with mulched lettuce having higher WC, followed by unmulched greenhouse and lower values for open field lettuce. There were no differences due to DAY but were differences for PREHARV. The mean WC for the whole plant in open field lettuce plants was lower than WC of unmulched greenhouse lettuce plants and mulched lettuce. In the middle and internal zones, the PREHARV and DAY interaction was significant. Both zones had similar results for greenhouse lettuce plants, where WC remained similar to that at harvest, and mulched WC was always superior to traditional greenhouse WC. Open field lettuce had increased WC by day 14 compared to harvest (1.5\% and $1.1 \%$ for middle and internal zones). Frequently, WC has been used to quantify water deficit in leaf tissue, so it is a useful indicator of plant water balance. Use of mulch reduces evaporation from the soil, resulting in a more uniform soil moisture regime. The whole plant water balance was better equilibrated in mulch compared with unmulched greenhouse, and was better than in open field.

The WC from the lettuce zones and heads from the production systems during refrigerated storage varied (Figure 1). Regardless of production system, no changes were detected in outer leaves, with WC values almost constant during storage. Differences detected at harvest among production systems were maintained during storage, with mean WC in external zone of open field lettuce plants lower than those for mulched and unmulched greenhouse heads. For middle and internal zones, no changes were detected in plants from greeenhouses, mulched and mulched during refrigerated storage, maintaining values similar to those at harvest. Open field lettuce increased WC values of middle and internal zones during storage (increments of $1.5 \%$ and $1.1 \%$, respectively). Frequently, WC is been used to quantify water deficit in leaf tissue, so it is a useful indicator of plant water balance. In the greenhouse evaporation is reduced resulting in a more uniform soil moisture regime. The whole plant water balance was better equilibrated and there was better performance in these plants. The increase in WC in middle and internal zones of lettuce plants produced in open field could indicate higher respiration activity, but this hypothesis must be established with specific studies measuring, for example, carbon reserves in the cell.
E

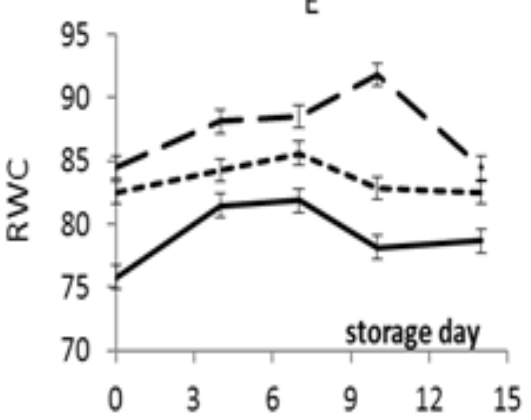

M

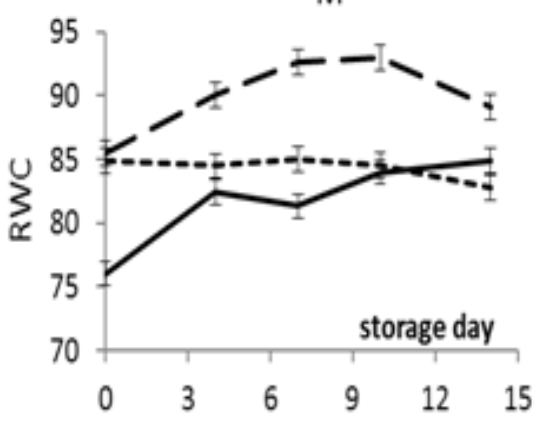

I

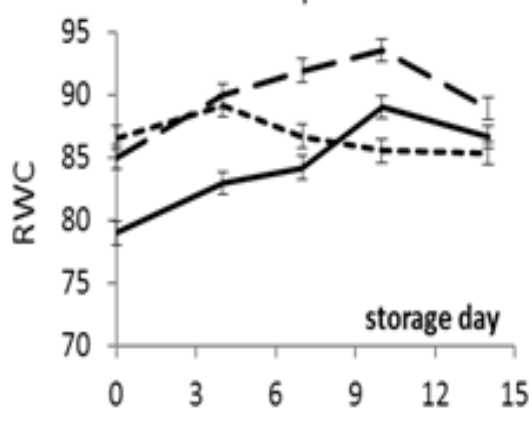

—OF $\because-M$ MG - -TG

E

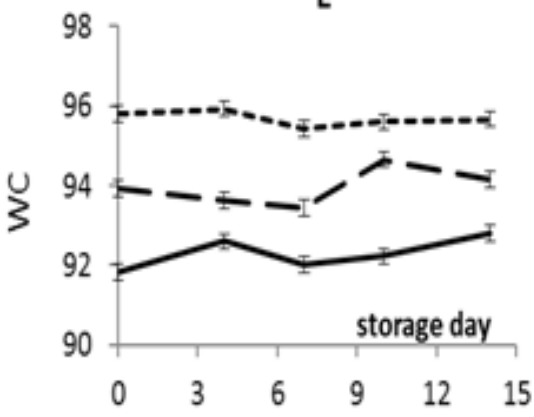

M

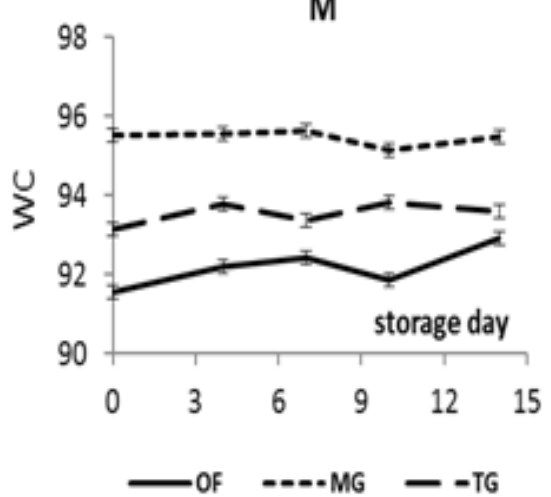

I

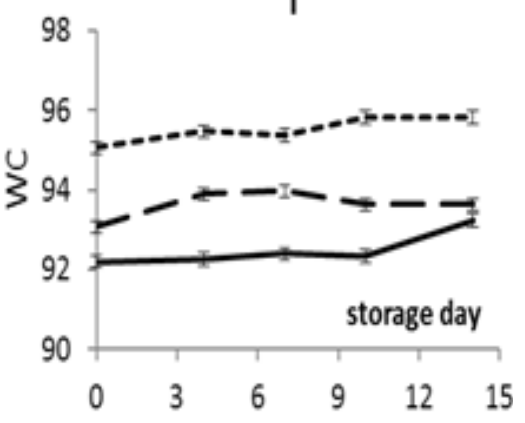

Figure 1: Relative Water Content (RWC) and Water Content (WC) evolution during refrigerated storage $\left(0-2^{\circ} \mathrm{C}\right)$ of Butterhead lettuce by zone $(\mathrm{E}$ : external, $\mathrm{M}$ : middle, I: inner) and production system (OF: open field, MG: mulch greenhouse, TG: traditional greenhouse). 
Citation: María GG, María del RM, María VA, Sara I R (2013) Impact of Production System on Quality Indices Distribution in Butterhead Lettuce: A Comparative Study among Open Field and Greenhouse. J Nutr Food Sci 3: 241. doi: 10.4172/2155-9600.1000241

Page 6 of 10

During storage, the tendency of FW was to remain unchanged or decline slightly, always higher in greenhouse lettuce plants (Figure 2). A triple interaction was found and results are again presented by ZONE. The FW in external leaves of open field lettuce plants maintained its value. Although higher FW occurred in freshly harvested mulched lettuce respect to unmulched greenhouse lettuce, no differences were found by day 14 , with a mean value of $12.44 \mathrm{~g}^{-\mathrm{g}^{-1}}$. In the middle zone, FW of open field lettuce plants had a decrease by the end of storage (65\% less) while the inner leaves FW remained relatively constant $(5.62$ $\left.\mathrm{g} . \mathrm{g}^{-1}\right)$. In both zones, unmulched greenhouse lettuce maintained similar FW during storage, with mean value of $10 \mathrm{~g} \cdot \mathrm{g}^{-1}$. The middle leaves from mulched lettuce had a $20 \%$ decreased in FW by day 14 , while it remained constant for inner leaves. Agüero et al. [8] also reported similar results for lettuce.

The BW increased for all production systems and zones (Figure 2).
The increased BW during storage could be a tissue response to harvest stress. An increase in BW can be associated with solute accumulation, leading to better osmotic adjustments and tolerance to water stress [42]. Since high relative humidity inside packages impaired dehydration, the BW increase during storage cannot be associated with water stress but be associated with maintenance of structural integrity and turgidity [8]. Harvest implies the removal of nutrient and water and tissues respond by increasing BW in cells.

The FW/TW had similar results compared to BW (Figure 2), where the only significant interaction was PREHARV and ZONE. Open field lettuce plants had lower FW/TW than greenhouse lettuce plants, regardless of the zone. External and middle leaves had similar FW/ TW for mulched and unmulched greenhouse production while in the internal zone, unmulched greenhouse lettuce plants had higher FW/ TW than did mulched. Agüero reported that FW/TW play a key part in
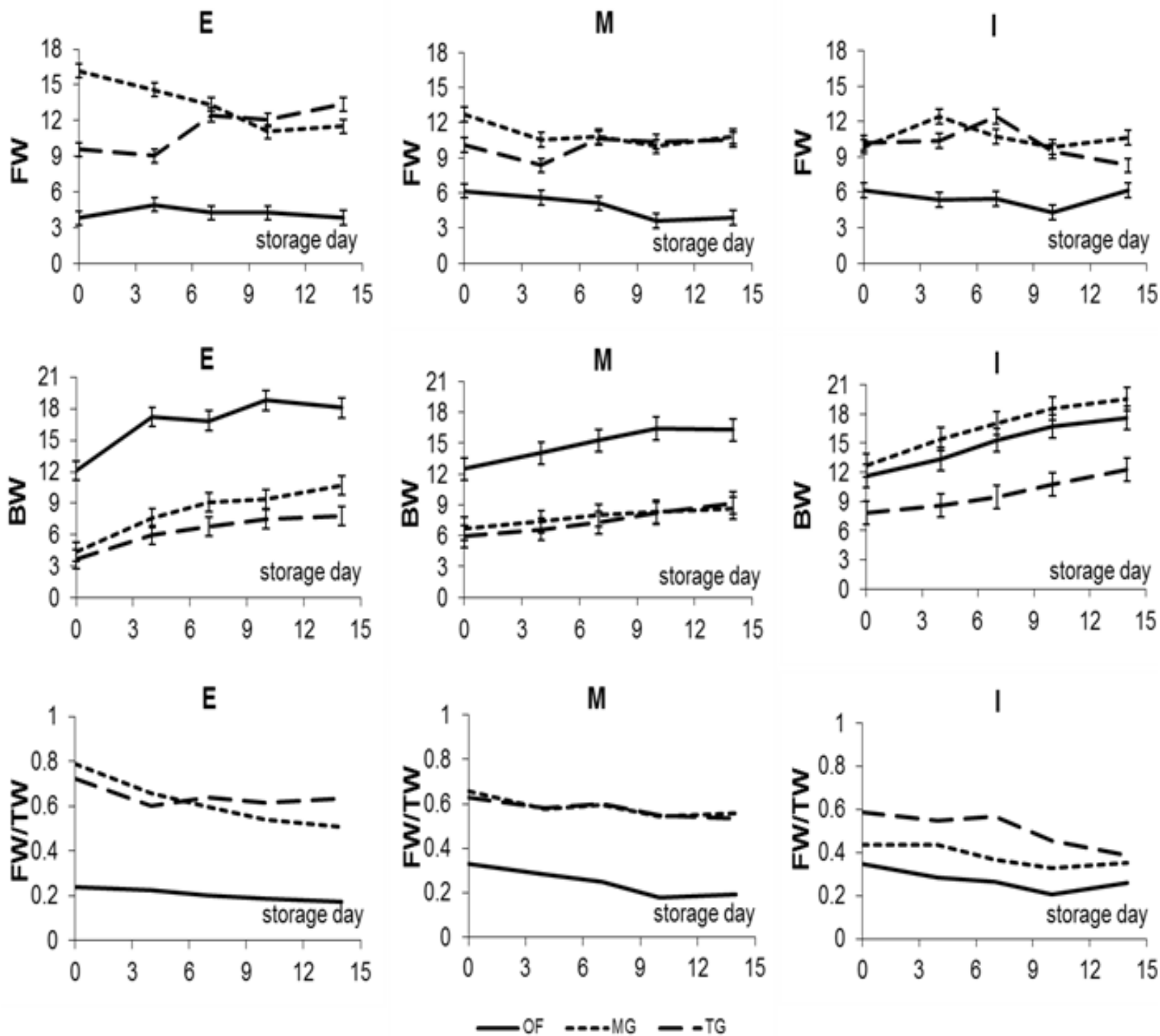

Figure 2: Free Water Content (FW), Bound Water Content (BW) and Relation Free Water /Total Water (FW/TW) evolution during refrigerated storage $\left(0-2^{\circ} \mathrm{C}\right)$ of Butterhead lettuce by zone (E: external, M: middle, I: inner) and production system (OF: open field, MG: mulch greenhouse, TG: traditional greenhouse). 
Citation: María GG, María del RM, María VA, Sara I R (2013) Impact of Production System on Quality Indices Distribution in Butterhead Lettuce: A Comparative Study among Open Field and Greenhouse. J Nutr Food Sci 3: 241. doi: 10.4172/2155-9600.1000241

Page 7 of 10

the shelf-life of each lettuce zone, being related to leaf texture which is an important quality parameter in lettuce $[8,43]$.

The FW/TW during storage changed (Figure 1). Open field lettuce plants had lower FW/TW than greenhouse lettuce plants, regardless of zone. No differences were detected in FW/TW values of outer- and mid-leaves for lettuce heads produced in greenhouses. In the internal zone, unmulched greenhouse lettuce plants had higher FW/TW than mulch. Slight decreases were detected in FW/TW values during storage. Agüero reported that FW/TW had a key part in shelf-life of each zone, and was related to leaf texture an important quality parameter $[8,43]$.

Nutritional quality of lettuce heads was affected by the production system used and by the placing of the leaves within the plant (zones) as presented in Figure 3. As early as day 4, a significant reduction in ascorbic acid content occurred in external and middle zones, especially in unmulched greenhouse plants. These reductions were detected in other production systems but with lower values for mulched and open field lettuce, without differences between production systems. For external and middle zones of heads cultivated in open field and mulched greenhouse, a linear model was fitted to the data. The AA degradation rate (slope) was higher in open field lettuce plants than in mulched plants. For traditional greenhouse lettuce plants, no linear model could be fitted to AA data from these two zones because they exhibited faster degradation with greater changes in the first days of storage. In the internal zone, no differences occurred in AA behavior in lettuce
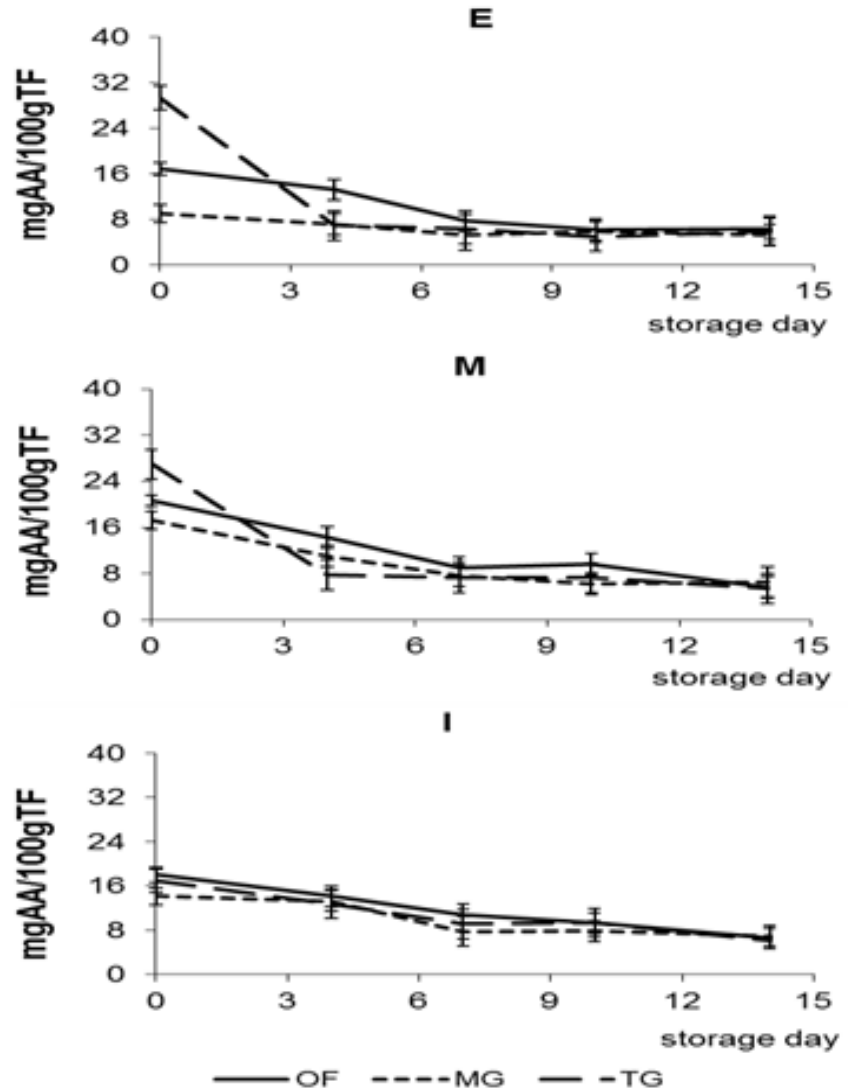

Figure 3: Reduced Ascorbic Acid (AA) evolution during refrigerated storage $\left(0-2^{\circ} \mathrm{C}\right)$ of Butterhead lettuce by zone (E: external, M: middle, I: inner) and production system (OF: open field, MG: mulch greenhouse, TG: traditional greenhouse). heads cultivated under the production systems, with a downward trend during postharvest storage. In these leaves, AA reduction followed a linear tendency. At day 14, AA content was similar for all lettuce zones and production systems with a mean value of $5.85 \pm 0.67 \mathrm{mg} / 100 \mathrm{~g}$ FT. Percent of reduction in the present work were expected given the liability of AA [44] and allowed reaffirming the need for development of new pre- and post-harvest technologies to maintain the nutritional value of freshly harvested vegetables.

Regardless of production system and zone, increases in TMB occurred during storage (Figure 4). Preharvest conditions seem to have an effect on microbial populations during refrigerated storage. Although no differences were found between growth rate of TMB from open field and traditional greenhouse lettuce plants, growth rate in mulched lettuce plants was lower. Ponce and Agüero found differences in the dynamic of microbial populations due to production system and attributed it to environmental conditions during primary production $[8,10]$. They proposed that growth of mulch lettuce in a controlled environment allowed bacteria to proliferate in a more benign environment and could enhance their susceptibility to cold storage. The TMB during refrigerated storage were different between lettuce zones. At day 14 , the differences in TMB were not significant among zones ( $9.3 \mathrm{log}$ ) but had increments of 63,40 and $51 \%$ for external, middle and internal zones, respectively.

Changes in CI during postharvest storage (Figure 5) indicated
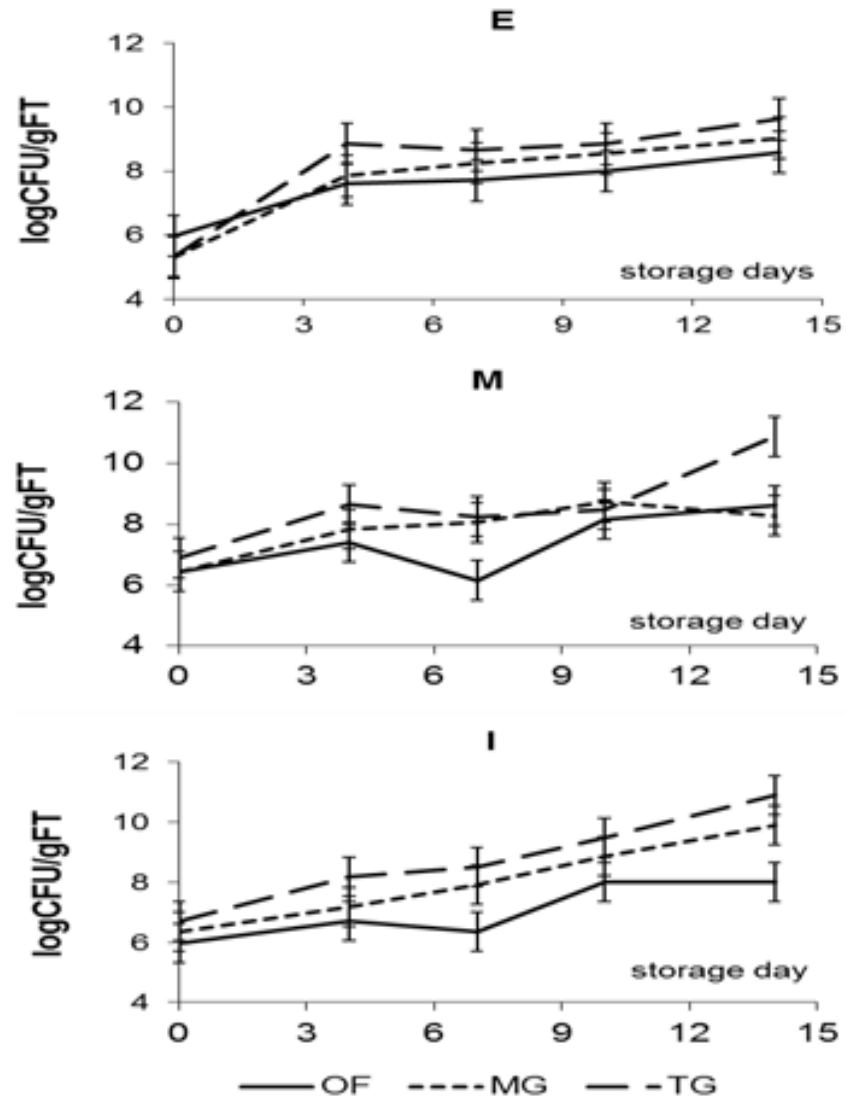

Figure 4: Mesophylic Total Count (log CFU / g FT) evolution during refrigerated storage $\left(0-2^{\circ} \mathrm{C}\right)$ of Butterhead lettuce by zone (E: external, M: middle, I: inner) and production system (OF: open field, MG: mulch greenhouse, TG: traditional greenhouse). 
effects on color retention, according to production system. Unmulched greenhouse lettuce maintained its color in external and middle zones throughout storage reaching, at day 14 , similar values to those at harvest. Open field and mulched lettuce plants exhibited alternating increases and decreases during storage. For internal leaves, unmulched greenhouse lettuce plants had greener leaves compared to mulched and open field plants, which were similar. During storage, increased yellowing of these leaves occurred with a linear function. For inner leaves, unmulched greenhouse lettuce, with the greenest value at harvest, had a yellowing response with a linear function, while inner leaves from the other production systems maintained this index almost constant until the end of storage.

Changes occurred in TC during storage (Figure 5). Significant reductions occurred in all situations. As at the beginning of storage, open field lettuce plants had the highest TC values, compared to greenhouse plants. No significant differences among greenhouse systems occurred. The external zone, in all production systems, had higher TC values than did middle and internal zones. The TC losses during refrigerated storage were fit linear functions in all lettuce zones, and production systems, with a degradation rate of $-0.5 \mathrm{mg}$ TC/ $100 \mathrm{~g}$ FT. These results indicate sensitivity of chlorophyll pigment to postharvest storage. The TC reduction by day 14 (26\% for open field and $22 \%$ for both greenhouse lettuce) might be responsible for the CI increased, even though other factors may also affect overall color perception, such as enzymatic browning dehydration [45-47].
Enzymatic browning is a cause of quality loss during postharvest storage of lettuce, and often occurring at the end of shelf-life [32]. Enzymatic browning in the butt stem (EBB) (Figure 6) increases during storage in plants in all production systems. The EBB score for open field lettuce heads reached a value by day 4 , indicating rejection of the product, while traditional greenhouse lettuce was rejected at day 10. Mulched lettuce heads did not surpass the acceptance limit in the present study. Enzymatic browning in leaves (EBL) (Figure 7) had a similar trend to $\mathrm{EBB}$, with a better performance in greenhouse lettuce zones (a slight increase only in external and middle zones towards the end of storage reaching values below the acceptance limit), but with increases in zones from plants cultivated in open filed. The acceptance limit for EBL in these plants was surpassed by day 7 in the external zone, and by day 14 in middle and internal zones.

The OVQ varied (Figure 7). Lettuce heads cultivated in the greenhouse had high OVQ values until day 8 of storage. After this values in external and middle zones decreased, were higher in unmulched than in mulched greenhouse, but OVQ values were always higher than 5 (acceptability limit). The internal zone of these plants did not change during storage. The three zones had decreases from the first days of storage, reaching the acceptability limit value towards the end of the period. The external zone reached this limit before (day 10) than did middle and internal zones. Open field lettuce plants lost near $40 \%$ of quality, by day 14 . At the end of storage, the unmulched greenhouse lost almost $20 \%$ of quality, as a function OVQ; mulched lettuce plants only
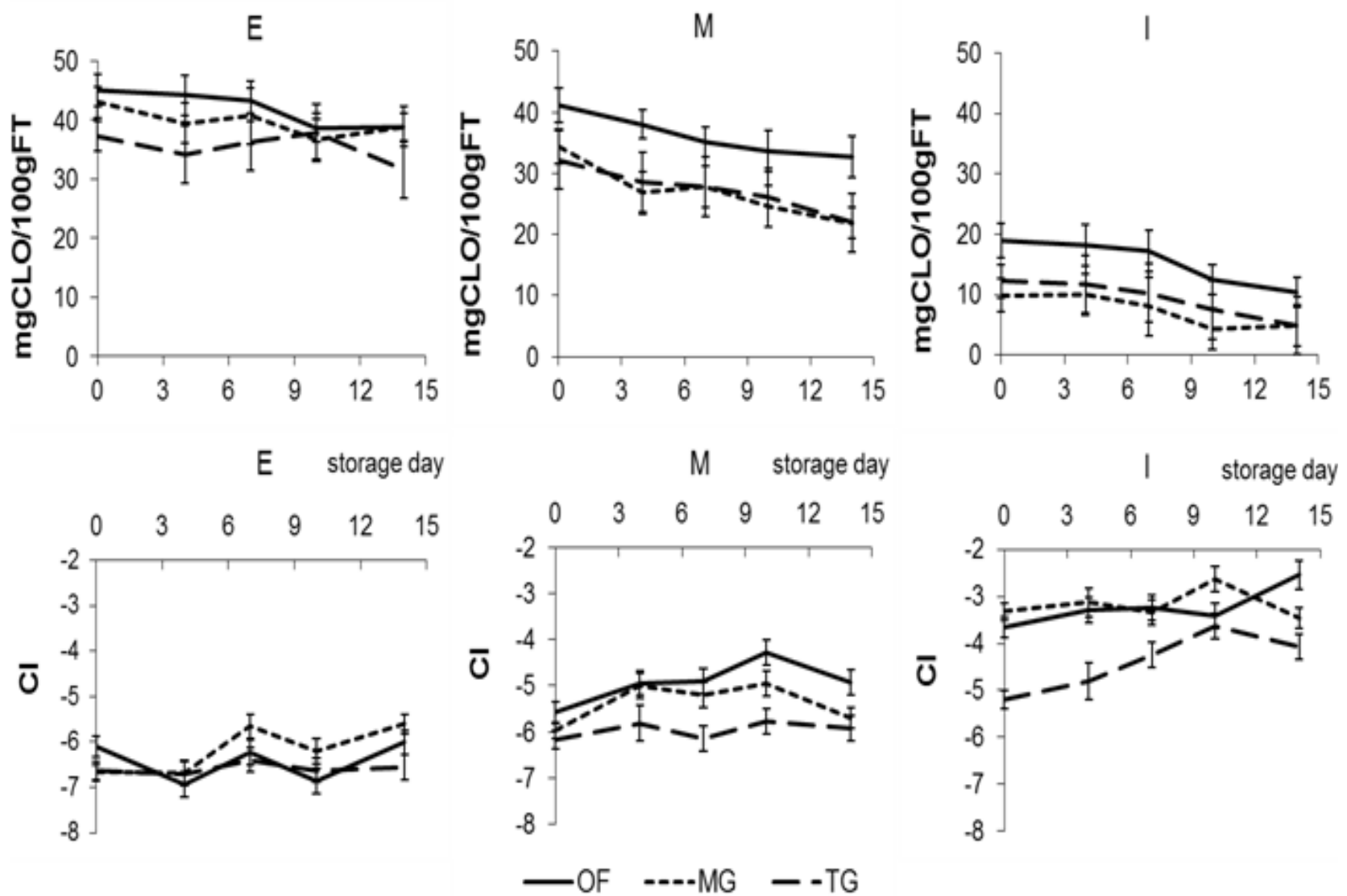

Figure 5: Chlorophyll content $(\mathrm{CLO})$ and Color Index $(\mathrm{Cl})$ evolution, during refrigerated storage $\left(0-2^{\circ} \mathrm{C}\right)$ of Butterhead lettuce by zone $(\mathrm{E}$ : external, $\mathrm{M}$ : middle, I: inner) and production system (OF: open field, MG: mulch greenhouse, TG: traditional greenhouse). 
Citation: María GG, María del RM, María VA, Sara I R (2013) Impact of Production System on Quality Indices Distribution in Butterhead Lettuce: A Comparative Study among Open Field and Greenhouse. J Nutr Food Sci 3: 241. doi: 10.4172/2155-9600.1000241

Page 9 of 10

lost $8 \%$. These results, combined with those for enzymatic browning, represent positive commercial advantages since shelf-life of mulched lettuce was longer than open field or unmulched greenhouse.

At harvest, greenhouse plants were heavier than open field lettuce, with fewer, but larger, leaves. This could be considered an advantage by consumers because less preparation would be required. Greenhouse

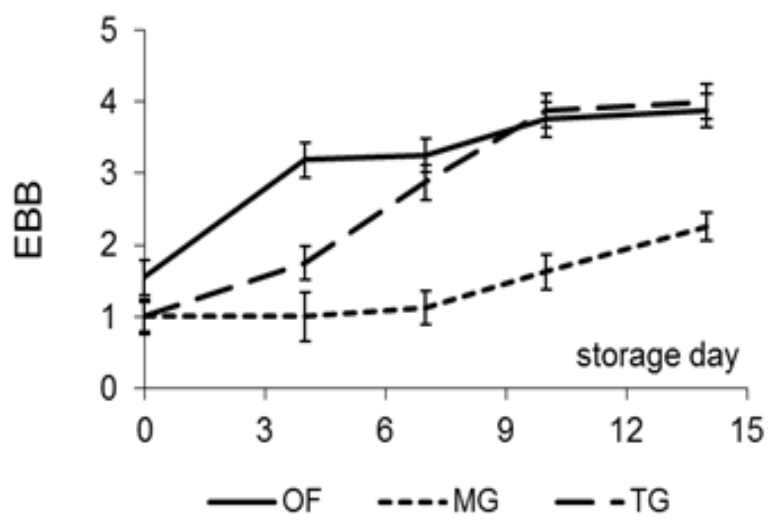

Figure 6: Enzymatic browning in butt stem (EBB) evolution during refrigerated storage $\left(0-2^{\circ} \mathrm{C}\right)$ of Butterhead lettuce by production system (OF: open field, MG: mulch greenhouse, TG: traditional greenhouse) lettuce plants had better water status at harvest. Open field lettuce had higher BW, probably as a physiological response to mild water stress during development. Nutritional quality at harvest was affected by the production system, with middle leaves of unmulched greenhouse lettuce having higher AA at harvest. No differences were found for microbiological indices, with microbial counts higher than $5 \log$ in all situations. Open field lettuce plants had lower OVQ scores and more enzymatic browning than greenhouse lettuce plants.

During postharvest storage use of greenhouses produces heads with higher initial quality, and better tolerance to refrigerated storage, with no differences between plants from unmulched or mulched greenhouses. The most noticeable changes during postharvest storage were to sensory quality. Open field lettuce plants had lower OVQ scores and more enzymatic browning than greenhouse lettuce plants, indicating lower quality. Open field lettuce plants reached the limit of acceptability by day 7 for the external head zone and by day 14 for middle and internal zones. Greenhouse lettuce plants did not reach the acceptance limit during the 14 days of storage.

The use of greenhouses for production of Butterhead lettuce may be beneficial due to increased yields and may represent improvement of initial quality and better retention of the quality during refrigerated storage. Shelf-life could be increased, another advantage for producers because longer shelf-life may lead to the possibility of reaching other markets.

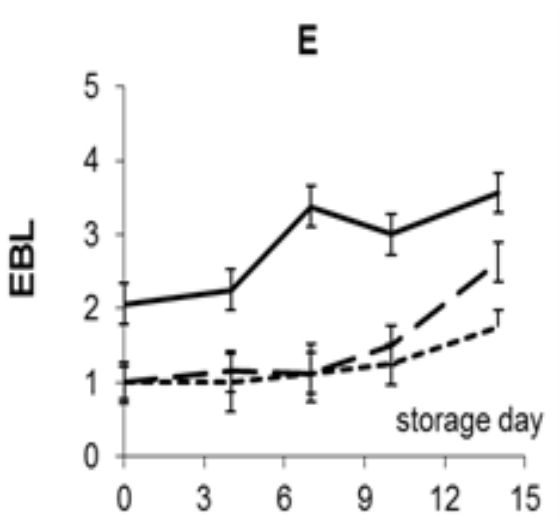

E

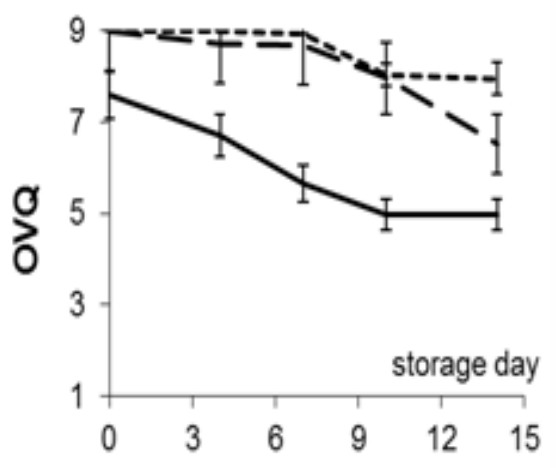

M

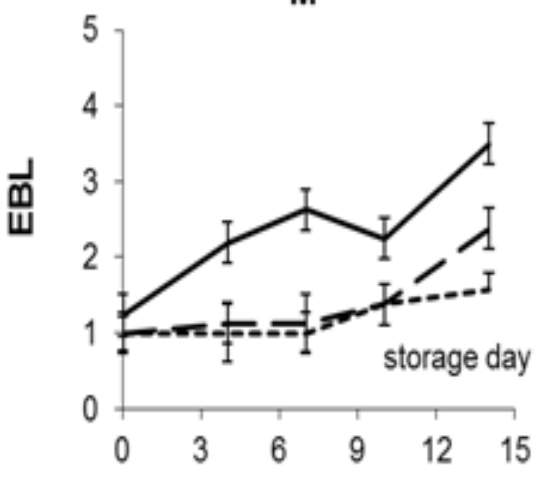

M

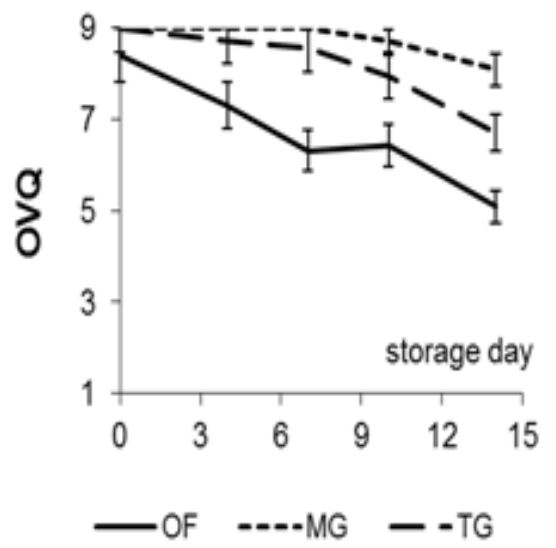

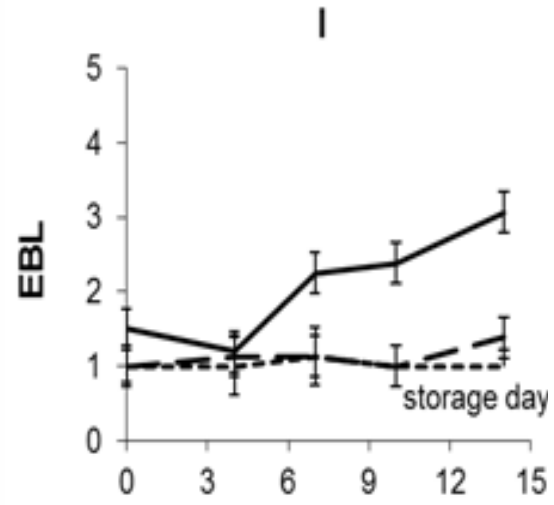

I

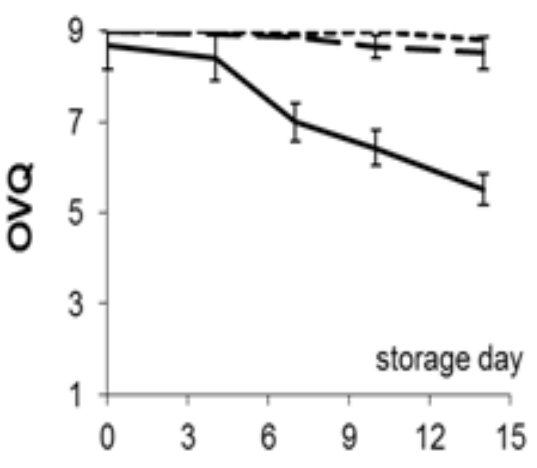

Figure 7: Enzymatic browning in leaves (EBL) and Overall Visual Quality $(\mathrm{OVQ})$ evolution during refrigerated storage $\left(0-2^{\circ} \mathrm{C}\right)$ of $\mathrm{Butterhead}$ lettuce by zone (E: external, M: middle, I: inner) and production system (OF: open field, MG: mulch greenhouse, TG: traditional greenhouse). 
Citation: María GG, María del RM, María VA, Sara I R (2013) Impact of Production System on Quality Indices Distribution in Butterhead Lettuce: A Comparative Study among Open Field and Greenhouse. J Nutr Food Sci 3: 241. doi: 10.4172/2155-9600.1000241

\section{Acknowledgements}

Work supported by Consejo Nacional de Investigaciones Científicas y Técnicas (CONICET), Agencia Nacional de Promoción Científica y Tecnológica (ANCyT) and Universidad Nacional de Mar del Plata (UNMDP). Paper is a partial fulfillment of requirements for the degree of Magister Scientiae in Vegetable Production, College of Agronomy, UNMDP of María G. Goñi.

\section{References}

1. Negi PS, Roy SK (2000) Effect of blanching and drying methods on $\beta$-carotene, ascorbic acid and chlorophyll retention of leafy vegetables. LWT - Food Science and Technology 33: 295-298.

2. Romani A, Pinelli P, Galardi C, Sani G, Cimato A, Heimler D (2002) Polyphenols in greenhouse and open-air-grown lettuce. Food Chem 79: 337-342.

3. Nicolle C, Cardinault N, Gueux E, Jaffrelo L, Rock E, et al. (2004) Health effect of vegetable-based diet: lettuce consumption improves cholesterol metabolism and antioxidant status in the rat. Clin Nutr 23: 605-614.

4. Kader AA (2002) Quality parameters of fresh-cut fruit and vegetable products. Lamikanra, O. (Edn) CRC Press.

5. Wien HC (1997) Lettuce. Wien, H.C. edn. In: The Physiology of Vegetables Crops. CAB International. New York. pp 479- 509.

6. Casanova PM, Messing I, Joel A, Cañete MA (2009) Methods to estimate lettuce evapotranspiration in greenhouse conditions in the central zone of Chile. Chilean J Agric Res 69: 60-70.

7. Radin B, Reisser CJ, Matzenauer R, Bergamaschi H (2004) Crescimento de cultivares de alface conduzidas em estufa e a campo. Horticultura Brasileira 22: $178-181$

8. Agüero MV, Barg MV, Yommi A, Camelo A, Roura SI (2008) Postharvest changes in water status and chlorophyll content of lettuce (Lactuca sativa L.) and their relationship with overall visual quality. J Food Sci 73: 176-185.

9. Fontanetti verdial M, Santos de lima M, Morgor AF, Goto R (2001) Production of Iceberg lettuce using mulches. Scientia Agricola 58: 737-740.

10. Ponce AG, Agüero MV, Roura SI, Del Valle CE, Moreira MR (2008) Dynamics of Indigenous microbial population of Butterhead lettuce grown in mulch and on bare soil. J Food Sci 73: M257-M263.

11. Goñi MG, Agüero MV, Moreira MR, Ponce A, Roura SI (2010) Ring characterization of quality indices in butterhead lettuce cultivated under mulch and bare soil. J Food Quality 33: 439-460.

12. Viacava GE, Roura SI, Agüero MV (2011) Improvement of water status methodology for leafy vegetables reduces consumption of time, skilled labor, and laboratory resources. Food Analytical Methods 4: 307-312.

13. Roura SI, Moreira MR, Ponce A, del Valle CE (2003) Dip treatments for fresh Romaine lettuce. Italian Journal of Food Science 15: 405-415.

14. ICMSF (1983) Métodos recomendados para el análisis microbiológico en alimentos. En: Microorganismos de los alimentos I. Técnicas de análisis microbiológicos, (2nd edn). Zaragoza, España.

15. Westland J(2001) Qué es el espacio de color CIE L*a*b*?.

16. Vignoni LA, Cásari RM, Forte M, Mirábile ML (2006) Determinación del Índice de Color en Ajo Picado. Información Tecnológica 17: 63-67.

17. Moreira MR, Roura S, Del valle C (2003) Quality of Swiss chard produced by conventional and organic methods. LWT - Food Science and Technology 36 $135-141$

18. SAS Inc. (2002) SAS software, Version 9.0 of the SAS System for Windows. SAS Institute Inc., Cary, NC, USA

19. Kuehl R (2001) Diseño de Experimentos 2da ed. Thompson Learning Intl. 666 p.

20. Blanco FF, Folegatti MV (2005) Estimation of leaf area for greenhouse cucumber by linear measurements under salinity and grafting. Scientia Agricola 62: $305-309$.

21. Frantz JM (2010) The greenhouse environment: heat and light. USDA.

22. Eitel JUH, Gessler PE, Smith AMS, Robberecht R (2006) Suitability of existing and novel spectral indices to remotely detect water stress in Populus spp. Forest Ecology and Management 229: 170-182.

23. Hsiao TC, Acevedo E (1974) Plant response to water deficits, water-use efficiency and drought resistance. Agricultural Meteorology 14: 59-84.
24. Guerra N, Carrozzi L, Goñi MG, Roura S, Yommi A (2010) Quality characterization of celery (Apium graceolens L.) by zones of plant and two harvest dates. J Food Sci 75: S327-S332.

25. Rascio A, Russo M, Platani C, Di fonzo N (1998) Drought intensity effects on genotypic differences in tissue affinity for strongly bound water. Plant Sci 132 121-126.

26. Roura SI, Moreira MR, Crapiste G, Del valle CE (2001) Biochemica characterization of two pepper varieties in green and red maturation stages. Italian Journal of Food Science 4: 391-397.

27. Toledo MEA, Ueda Y, Imahori Y, Ayaki M (2003) L-ascorbic acid metabolismo in spinach (Spinacia oleracea L.) during postharvest storage in Light and dark. Postharvest Biology and Technology 28: 47-57.

28. Wojciechowska R, Siwek P, Libik A (2007) Effect of mulching with various films omn the yield quality of butterhead lettuce and celery stalks with special reference to nitrate metabolism. Folia Horticulturae 19: 37-44.

29. Liakatas A, Clark JA, Monteith JL (1986) Measurements of the heat balance under plastic mulches. I: Radiation balance and soil heat flux. Agricultural and forest meteorology 36: 227-239.

30. Arrigoni O, De Tullio MC (2002) Ascorbic acid: much more than just an antioxidant. Biochim Biophys Acta 1569: 1-9.

31. Bartoli CG, Tambussi EA, Diego F, Foyer CH (2009) Control of ascorbic acid synthesis and accumulation and glutathione by the incident light red/far red ratio in Phaseolus vulgaris leaves. FEBS Letters 583: 118-122.

32. Franck C, Lammertyn J, Tri Ho Q, Verboven P, Verlinden B, et al. (2007) Browning disorders in pear fruit. Postharvest Biology and Technology 43: 1-13.

33. Oh MM, Carey EE, Rajashekar CB (2009) Environmental stress induce healthpromoting phytochemicals in lettuce. Plant Physiol Biochem 47: 578-583.

34. Smirnoff N (1996) The function and metabolism of ascorbic acid in plants Annals of Botany 78: 661-669.

35. Ponce AG, Roura SI, Del valle CE, Fritz R (2002) Characterization of native microbial population of Swiss Chard (Beta vulgaris, type cicla). LWT - Food Science and Technology 35: 331-337.

36. Zagory D (1999) Effects of post-processing handling and packaging on microbial populations. Postharvest Biology and Technology 15: 313-321.

37. Fonseca JM (2006) Postharvest quality and microbial population of head lettuce as affected by moisture at harvest. J Food Sci 71: M45-M49.

38. Caldwell CR, Britz S (2006) Effect of supplemental ultraviolet radiation on the carotenoid and chlorophyll composition of greenhouse-grown leaf lettuce (Lactuca sativa L.) cultivars. Journal of Food Composition and Analysis 19 637-644.

39. Winkel-shirley B (2002) Biosynthesis of flavonoids and effects of stress. Current Opinion in Plant Biology 5: 218-223.

40. Carletti P, Masi A, Wonisch A, Grill D, Tausz M, et al. (2003) Changes in antioxidant and pigment pool dimensions in UV-B irradiated maize seedlings Environmental and Experimental Botany 50: 149-157.

41. Ingram J, Bartels D (1996) Thtte molecular basis of dehydration tolerance in plants. Annual review of plant biology 47: 377-403.

42. Singh V, Pallaghy CK, Singh D (2006) Phosphorouos nutrition and tolerance of cotton to water stress II. Water relations, free and bound water and leaf expansion rate. Field Crops Research 96: 199-206.

43. Burdon J, Clark C (2001) Effect of postharvest water loss on "Hayward" kiwifruit water status. Postharvest Biology and Technology 22: 215-225.

44. Rodrigues CMA, Della lucia CM, Azeredo RMC, Cota AM, Santana AMC Pinheiro-santana HM (2010) Control of vitamin C losses in vegetables prepared at a food service. Food Control 21: 264-271.

45. Tomás-Barberán FA, Gil MI, Castañer M, Artes F, Salveit ME (1997) Effect of selected browning inhibitors on phenolic metabolism in stem tissue of harvested lettuce. J Agric Food Chem 45: 583-589.

46. Tano K, Oulé MK, Doyon G, Lfncki RW, Arul J (2007) Comparative evaluation of the effect of storage temperature fluctuation on modified atmosphere packages of selected fruit and vegetables. Postharvest Biology and Technology 46: 212-221.

47. Vega-gálvez A, Lemus-Mondaca R, Bilbao-sáinz C, Fito P, Andrés A (2008) Effect of air drying temperature on the quality of rehydrated dried red bell pepper (var. Lamuyo). J Food Eng 85: 42-50. 